\title{
Being a Fashion Designer in Montreal: Flexible Careers across the Life Course!
}

\author{
Amina Yagoubi, Diane-Gabrielle Tremblay \\ Business School, Teluq, University of Québec, Quebec City, Canada \\ Email: dgtrembl@teluq.ca, ayagoubi@teluq.uquebec.ca
}

Received 15 August 2016; accepted 3 September 2016; published 6 September 2016

Copyright (C) 2016 by authors and Scientific Research Publishing Inc.

This work is licensed under the Creative Commons Attribution International License (CC BY). http://creativecommons.org/licenses/by/4.0/

c) (i) Open Access

\begin{abstract}
Our article addresses the evolution of the fashion designer career over the last century, and situates this in the context of the "creative city" of Montréal: "UNESCO City of design" (2006). In the context of the complex world of local fashion, one form of the World of Art [1], we explore the reality of the flexible career and theprecarious form of work of fashion designers in Montreal. For this, we present a brief historical overview of the development of the profession in order to understand how the profession of fashion design has emerged locally and how careers have developed and transformed over the years and the designers' life courses. After this overview, we examine the more recent development and the new vision of this profession in the context of the creative economy and particularly the paradox of a career situated between the artistic endeavour and the entrepreneurial and financial challenges. Methodologically, this study is based on a literature review as well as on three series of interviews conducted over the past years (2010-2013) with some (48) designers as well as organizations and associations working in the fashion industry. However, here we use mainly the case of one designer, Jean-Claude Poitras, as a particular illustration.
\end{abstract}

\section{Keywords}

Creative Careers, Creative City, Fashion Design, Montreal

\section{Introduction}

Over recent years, a major contribution of sociology of work and socio-economics has been to identify various processes of segregation and selection in the labour market. These effects tend to be reinforced when job opportunities are scarce and in where embedded social values play an on-going part. As a consequence, jobs have diversified, and self-employment in particular has increased in many countries. Jobs of greatly varying quality continue to coexist within the same market and sometimes within the same firm. Analyzing these issues, some 
researchers refer to the notion of "bad jobs" [2] others to non-standard or flexible working arrangements, and still others' concerns are focused on weak employment relationships [2], or the break with the traditional internal labour markets [3] [4].

The implication is clear: the notion of a labour market comprised only of well paid "good jobs" characterized by individual responsibility, intellectual challenge, open communication and trusting relations flies in the face of evidence that shows that many, in particular youth, women and visible minorities are not in such jobs and actually do not have fair access to such jobs. Artistic and creative jobs are often in that situation as well [5] [6], and self-employment in these sectors often translates into irregular contracts and pay, especially at the start of the career or life course.

It is impossible to identify any single dominant force (such as globalization or technology) shaping work and employment. Unlike those who speak of the spread of the "high performance" organization or who project the end of the division of labour and the advent of enriching jobs [7], the reality is much more complex. A diversity of employment situations-good, bad and middle-ground-will continue to be observed.

In this context, and also taking into account the World of Art [1], we explored the careers of fashion designers in Montreal. We consider that these designers are amongst the groups at the front of the changes in the labour market, moving from traditional careers to more contingent and "boundaryless" careers [8] and this is what we seek to demonstrate in our paper, in two ways.

First, many designers have had to move into new types of careers, more flexible and uncertain trajectories over their life course, as is often the case in creative careers [9] [10]. Second, new designers coming into the labour market are directly projected into less stable careers, as the more traditional "internal labour market” careers have been replaced by nomadic, “boundaryless” careers [8]. Before we go into the analysis of designers” careers, let us first present a brief historical overview of the development of the profession in order to understand how the profession of fashion designer has emerged and developed locally, which also feeds into our first demonstration. After this overview, we examine the more recent development and the new vision of this profession, including the transformations and increased flexibility in life course trajectories of designers using in particular the case study of Poitras.

\section{The Life Course Perspective}

As we integrate our work in a life course perspective this means adopting a holistic view of situations, rather than focusing "on isolated specific events, phases or demographic groups as being discrete and fixed but considers the entire life as the basic framework for empirical analysis and policy evaluation. The link between individual trajectories on one hand and historical period, social structures, as well as human agency on the other, is also at the core of the life course paradigm” [11].

To summarize this view, while exploiting it somewhat, we present here the four elements that are highlighted by Bernard [12], and which we tried to take into account in our research, even if this is difficult with research spanning over 5 years only.

a) The life course perspective is based on the idea that life is longitudinal, and that constraints and opportunities from the past will have an influence on future trajectories, or careers in our case. For example, we could hypothesize that the presence of children and more constraining family situations might diminish the time available to individuals_-especially women_-and make it more difficult to develop their career in future years.

b) Life is multifaceted, in the sense that health, work, education and family issues are intertwined and the evolution of these variables has an impact on the others. We did not access information on all elements concerning designers, but we did see that education, having been to college or university with someone, could have an impact on developing a career project together.

c) Lives are linked through family and generational relationships. Family members thus impact on each other's life course. While we cannot develop fully on family issues here, some did mention that family issues or being without spouse or children do have an impact on career options.

d) Life unfolds in local communities. The quality of schools (Fashion schools in our case) and job or training possibilities of course vary from one region or city to another. The importance of three colleges of fashion in Montreal did have an impact, especially on the younger designers' careers.

\section{Methodology}

Methodologically, this study is based on a literature review as well as on interviews conducted over the past 
years (2010-2013) with some 48 designers (1 h 30 - 2 h) as well as organizations and associations working in the fashion industry, and as mentioned above, we use the case study of designer Jean-Claude Poitras as an illustration but put in context with interviews from other designers [13].

The study was based on interviews and internal data (reports, corporate documents, press articles, etc.). The interviews are semi-structured and open interviews with 23 designers and 25 intermediate actors (Sectorial and Intersectorial). The interviews lasted between one hour and a half to two hours each, and were done in four rounds, then fully transcribed. The first round of semi-structured interviews is based on a guide to trace the trajectories of Emerging Designer (ED, see the list of codes at end of paper also); the second round is based on open interviews aimed to collect the stories of Renowned Designer (RD) and pioneers (DP). The third round follows a guide developed towards Intermediate Sectorial Actors (ISA), Intermediate Intersectorial Actors (IIAS) and Political Intermediaries (IP) (semi-structured interviews). Finally, the fourth round is based on semi-structured interviews aimed towards Intermediate Promoter Industry (IPI) representatives. All interviews were subjected to a qualitative and thematic analysis [14]. We triangulated the data [15] from our various sources (interviews, official documents, information in social networks including Facebook, Twitter, etc.). In total, we interviewed:

- 16 Emerging Designers (ED) [Confirmed Emerging Designer (EDC), Renowned Emerging designer (EDR) and Beginner Emerging Designer: (EDB)];

- 7 Renowned Designer (RD) and Pioneers (DP);

- 17 intermediate actors, Sectorial and Intersectorial and political (ISA), (IIAS), (IP);

- 8 Intermediate Promoting Industry (IPI).

\section{The Emergence of the Profession of Fashion Designer ${ }^{1}$ in Montreal}

In order to keep the longitudinal perspective on the fashion world, we need to mention that the emergence of the profession of fashion designer in Quebec spreads over a period of 60 years and has a complex history. Emerging in a context of globalization and straddled by conflicting relationships with manufacturers, the heirs of industrial society, it had difficulties affirming itself. Toward the late 19th century, the clothing industry occupied a significant place in the local economy, whereas the fashion industry was nearly non-existent. In the early 20th century, looking towards Paris, the legendary capital of fashion, Montreal made its first steps in this arena. The years from 1920 to the post-war saw a proliferation of attempts at copying, thanks to recognized dressmakers [16]. Montreal then acquired a reputation for being a city that imports European fashion to North America, which also gave rise to a new phenomenon: the emergence of fashion in Quebec society.

Expo 67, the world's fair held in Montreal in 1967, marked an important milestone in the evolution of mentalities in Quebec. It coincided with the emergence of a global phenomenon, namely the arrival of high-end ready-to-wear clothing. Designer clothing and accessories for men and women with Quebec names began appearing in stores [16]. [Our translation; p. 10]

The milieu of fashion designers had difficulties consolidating throughout the second half of the 20th century. In the 1950s in Montreal, the profession struggled to maintain itself, in part because of poorly adapted political action and mismanaged finances. The first association of fashion designers in Canada, founded in 1954, sought to publicly promote collections by organizing fashion shows. Moreover, it aimed to begin structuring the sector and to win the support of intermediaries (financial, media, etc.), whereby Canadian fashion as well as the profession could gain recognition.

While ready-to-wear fashion gained ground in the world's major fashion capitals in the early 1960s, custom-fitted haute couture still persisted in Quebec. It took the shock of Expo 67 to change that. In 1968, the Association of Canadian Couturiers had become anachronistic, and terminated its activities. Some designers had difficulty adapting to the new context, while others like Michel Robichaud were quite comfortable in both worlds and engaged themselves enthusiastically in this fresh approach to fashion [17]. [Our translation: p. 278]

Nevertheless, Robichaud encountered challenges, which he described as follows.

Manufacturers with whom I came in contact with in Montreal let me know that I didn't have a name and

${ }^{1}$ For the history of fashion in Quebec, we refer to two essential works: [16] [17]. 
that I wasn't prestigious enough. They said they had good designers at their disposal and that they preferred going on with copying what was being done in Paris or New York. That was Quebec fashion at the time [...]. That's when I realized that I didn't have a choice and that I had to plunge into haute couture myself, in order to develop my own style and make a name for myself [17]. ${ }^{2}$ [Our translation: p. 280]

He received his training at the École de la chambre syndicale de couture parisienne (School of the Chambre Syndicale of Paris couture), aware that haute couture in Canada was not what it was in Paris, and worked with famous designers such as Nina Ricci and Guy Laroche. Upon his return in 1967, the manufacturers who didn’t want to work with him before came to solicit him for his high-end ready-to-wear fashion ${ }^{3}$. According to Robichaud, in Quebec from the 1950s on, fashion design and the garment industry were not engaged in a fruitful collaboration, due to which designers of this province evolved in isolation of the developments in Europe or the United States. Yet, the fashion profession is such that it requires considerable expenditures for the preparation and distribution of seasonal collections, as well as a delay of about six months before seeing any results. That is why this type of precarious creative professional must be able to prevent financial risks in order to grow and continue activities with multiples aid (formal and informal). Michel Robichaud spoke of the difficulties encountered when he tried to open up to foreign markets. He would have had to invest \$2 to \$3 million Canadian dollars, an amount he could not come up with because, unfortunately, "the Quebec fashion scene never seemed safe enough in the eyes of the financial community of the province, which had neither the means of Europeans or of US-Americans” [17] [Our translation: p. 282].

This entry of ready-to-wear fashion marked the beginning of the relationship between industrial garment manufacturing and creativity. Fashion designers then began defining their place in the international and local markets, between globalization and glocalization, and to engage in adding value to their output at a time when, from 1970 on, the garment industry in Quebec was facing the advent of globalization.

Manufacturers were beginning to see the value of the creators from here in order to give their production, or a part thereof, a distinctive character. [...] It was not surprising that in terms of media visibility and real presence in the socio-cultural dynamics, the creation of fashion experienced a heyday in the 1970s. After Expo 67, many designers who previously had a tailor-made practice began designing collections for manufacturing [17]. [Our translation: pp. 287-288]

This period evidences the transformation of the sector and the government decided to get involved in a practical way in order to give the sector the chance to focus on new niches and to continue developing its international business profile in the face of competition.

Governments began seeing the need to do more to strengthen the industry. Thus, the Quebec government in 1972 inaugurated a series of annual events [...] named Montréal Mode. The operation aimed to raise awareness of Montreal designers and manufacturers, especially in the United States. During this event, which had five editions from 1972 to 1976, buyers and media representatives were invited to visit the city and see the fashion shows [17]. [Our translation: p. 288]

The taking into consideration of these new challenges for the industry was accompanied with the creation in 1974 of a new organization called the Fashion Designers Association of Canada. Chaired by Michel Robichaud, this association had the mandate to ensure the visibility of new fashion creations and the organization of fashion shows. It lasted 10 years and was dissolved in 1980. During the same time, emerging fashion designers asserted themselves, among them Jean-Claude Poitras. A graduate from the École des métiers commerciaux (School of commercial business), Poitras made an international career, announcing in 1977 his Bof! Collection, which he had manufactured by Beverini. This designer definitely introduced a dynamic cultural and economic shift, characterized by the transition away from traditional haute couture and into the contemporary world of fashion design and a new mode of collaboration between industry, policies and designers. In this context, fashion designers became players in whom various intermediaries (political, industrial, media, etc.) invested in as sources of added value.

According to a recent study commissioned by the Apparel Human Resources Council [18], the post-industrial era is marked by an increase in white-collar jobs (service-oriented flexible work by professionals and techni-

\footnotetext{
${ }^{2}$ Interview with Michel Robichaud by Gérald Baril, Quebec designer who produced his first haute-couture collection in 1963.

${ }^{3}$ Design of a collection for Auckie Sanft.
} 
cians) and a decrease in blue-collar jobs (labour related to production), in contrast to the traditional industrial period marked by the "industry plant closures and massive layoffs" [18]. This is the case in the apparel manufacturing sector as well as others due to "the removal of import quotas and globalization" [18], in particular as of 2005.

Whereas the fashion industry of Montreal previously enjoyed a significant reputation in North America, occupying the third position after New York and Los Angeles, it now confronts "two shocks in quick succession" (ISA.1, our interview, see list of codes at end of paper). The first one came in 2003 with the opening of borders to "developing countries with North/South agreement [...], the poor countries" (ISA.1); the second came in 2005 with the "abolition of import quotas [...] the industry has completely collapsed!" (ISA.1). The elimination of trade barriers like tariffs and import quotas is achieved by most WTO countries in 2005. Moreover, in a context of globalization, most manufacturers were obliged to change their business model so as to be more responsive and by relocating some of their production. And, for Statistics Canada, "[domestic] production personnel and other value adders according to the new definition, would be classified as wholesale employees” [18], (p. 25).

This is why we cannot collect comprehensive data on the distribution of trades or the emergence of new activities and new ways of doing things. The industrial crisis as well as the former situation of the apparel industry thus continues to feed the discourse (media, Labour department, etc.). The restructuring of the apparel and fashion industry in Quebec was marked by the desire to develop creativity and innovation and to explore various new niches (ecological, ethical, intelligent, clothing, etc.) which may be easier to access, especially for young designers, than the haute-couture, reserved to a few places on the globe.

The industry definition adopted by the Council as well as those adopted in other jurisdictions serve to redefine the industry-not based on the location of the sewing machines-but based on the nature of the value added activities being performed domestically [18], (p. 25).

Fashion designers occupied a strategic place in this transformation, as the new "white collars" of the value chain, responding to the challenges brought by globalization, including those concerning the marketing of apparel [18]. In Montreal, more and more actions took place to strengthen the local economy, for example, actions promoting the development of business relationships between designers and retailers. In September 2010, the highly mediatized Philippe Dubuc produced a collection for a boutique called Simons, for whom he later produced a men's collection. At the same time, the famous designer Denis Gagnon exhibited in the Museum of Fine Arts in Montreal (MMFA) in October 2010 after exhibits by Yves Saint Laurent and Jean-Paul Gaultier ${ }^{4}$ and delivered a fall collection for the boutique Bedos in August 2010. The encouragement of relationships between business, public actors and fashion designers in the midst of a changing environment contributed to the building of the image of Montreal as a Fashion City and to the visibility and social recognition of its designers, all the while working conditions were changing in the industry and designers were becoming more visible, if not necessarily with stable working conditions, but rather short-term contracts.

\section{Montreal, Hub of Fashion \& Design, a Positive Context for Designers' Careers}

In order for designers to develop their career and eventually have a reputation, they need to be supported by a positive image of the place where they work. It is extremely difficult in this sector to build a reputation outside of the local context. While New-York, Paris and Milan are well-known for high-end fashion, Montreal is part of a second tier of cities (Antwerp, Munich and others) that need to build their creative image in order to support artists and fashion designers' careers.

In May 2005, an international conference was held in London (London College of Fashion and Museum of London) to discuss the relationships emerging between fashion and megacities. It found that the status of fashion capital was becoming a new coveted mark of distinction among cities [19]. The Creative Cities Network of UNESCO seeks to highlight the creative industries of a list of second-tier cities [20] in an effort to promote their local economies and their access to a supranational visibility. The designation of emerging creative cities introduces a shift, at least symbolically, in the traditional notion of one predominant cultural capital and invites us to consider that there might be other creative hubs. UNESCO proposes the following definition of the creative city:

${ }^{4}$ La planète mode de Jean Paul Gaultier, de la rue aux étoiles, (The Jean Paul Gaultier Fashion Planet, from the street to the stars) Montreal Museum of Fine Arts, from June 17 to October 2, 2011. 
The concept of "Creative Cities" is based on the belief that culture can play an important role in urban renewal. Policy makers are increasingly taking account of the role of creativity when planning economic policy [21].

The European Union stresses the importance of supporting the creative industry-consisting of different sectors such as film, music, publishing, media arts, fashion, industrial and interior design, cultural tourism, performing arts and heritage-because it is a growth industry that "generates five million jobs and represents $2.6 \%$ of the GDP in the 27 countries that make up the Union" [21] [our translation]. A report ${ }^{5}$ from the United Kingdom reveals that the concept of creativity is today triggering new urban policy orientations in areas not only pertaining to culture but also, and especially, to economy and the creative industries. The paradigms related to the organization or accompaniment of the advent of the creative society invite us to question the existing relationships between culture, creativity and the economy.

Through a number of public actions, Montreal has promoted its city and supported its local economy in order to create competitive creative niches. In 2006, the city acquired the status of UNESCO City of Design alongside Berlin (Germany), Buenos Aires (Brazil), Nagoya and Kobe (Japan), Shenzhen (China), Shanghai (PRC), Seoul (Republic of Korea), Saint-Etienne (France) and Graz (Austria). Following this designation, the Bureau de Design and the Bureau Mode Montréal (BMM) were created in 2009, proposing a new action plan, the fashion strategy "Montréal style libre" ${ }^{6}$ and a new interactive and evolving online tool, the Fashion Map, showing the locations of the different designers and their venues (shops, stores, retailers) across the different neighbourhoods. Therefore, the city is distinguished by developing its creative talents (Pilati, Tremblay, 2008; Pecqueur, 2006), by being simultaneously an Anglophone and a Francophone "young city" (ED.2, our interview), by offering a favorable environment: low cost rents and quality of life (ED.1, our interview), and it has a "superb fine reputation within the Canadian context” (ED.3, our interview) [10].

Thus, the development of the creative economy is likely to generate many advantages, even if it cannot be the sole guarantor of a reputation and career for designers. Indeed, the presence of a creative class in a city does not necessarily translate into better or more stable financial conditions for the inhabitants, or for the artists and designers in particular. However, the gentrification affecting so many cities can be said to take place precisely because of the presence of artists in certain neighbourhoods, although the artists are often forced to move out when the district becomes fashionable and rents go up.

The example of Montreal seems interesting due to the implementation of programs specific to fashion designers in keeping with the building of the city's image as a city of fashion. It allows us to understand what is really at stake and how this creative class [22] affirms itself in this environment. The report commissioned by Montreal to Richard Florida was supposed to present solutions for promoting the attractiveness of the city to creative players, namely for economic purposes, and even the development of creative tourism [23]. The process of restructuring the traditional apparel industry marked by the development of the creative niches is part of the same paradigm. This leads us to question the motivations of North American cities to embrace innovation and creativity as a means to deal with the complexity of the global economy. In the context of the creative city, the productions of fashion designers become a type of work to be recognized and appropriated by the metropolitan, regional and national cultures and spread internationally through policies.

The institutional management strategies of the creative and cultural industries, for their part, are often seen as indicative of the characteristics of a project at the heart of the trend toward megacities. The exhibition of the designer Denis Gagnon at the Museum of Fine Arts in Montreal in October 2010 is a good example. On the one hand, there are the municipal and provincial policies that support the development of fashion design and, on the other hand, cultural actors involved in reputable events in Montreal select a "living" fashion designer to exhibit in the museum. In this way, the city became connected to a "metropolitan archipelago" [23] and the cultural events it deploys are, by extension, connected to a broader level, namely that of the Creative Cities Network (of UNESCO).

In this complex economic environment, the creativity of fashion designers is necessary for Montreal to develop as a Fashion City. There is thus a reciprocal relation, as the city builds its image on the fashion designers, and the latter build their reputation on the image of Montreal as a Creative city, which supports their creative endeavours and trajectories. In this context, the actions of the city and the strategic plans concerning designers

\footnotetext{
${ }^{5}$ UK Trade \& Investment, 2009. “Creative Industries UK”. (90-page report).

${ }^{6}$ See www.montrealcartedemode.com.
} 
are fundamental for orienting the significant interactions between intermediaries and fashion professionals. They are also important for allowing to see the impact of this cooperation on, on the one hand, the career, reputation and professional identity of fashion designers and, on the other hand, the image of the fashion city at the local level, as studies of interventions of various intermediaries have shown.

In the remainder of this text, we examine the paths of fashion designers in such a changing environment where cooperation, negotiation, branding and recognition seem decisive in order to build a life course and career and try to counter the challenges of the boundaryless and often precarious career. Starting from an empirical and micro-sociological study, we compare the dual professional identity of the designer between entrepreneur and artist, and between the apparel and clothing industry on the one hand and the creative fashion industry and culture on the other.

In a market characterized by important risks, fashion designers must define their activities at a crossroads between productivity and creativity, and one on which they oppose globalization on the one hand yet, driven by a search for international recognition, paradoxically subscribe to the values of globalization on the other hand.

\section{The Artist as Innovator and Creative Entrepreneur}

The repositioning of artists and creators in contemporary society comes from the fact that they have to fit in a world where the idea of the cult of work [24] promoted by the bourgeois sphere in the last century does not play the same role. This has also been observed in the wake of recent developments in Montreal, where the creator becomes more and more an entrepreneur. Based on the analysis of bourgeois society, Daniel Bell [25] shows that a hedonistic individualism profoundly changed the values of capitalism, as does Menger [24] also. Menger [24] developed the idea of a new kind of worker, a type of member of the avant-garde who combines the vocation of artist with the entrepreneurial spirit, "as if one represented the essence (the artistic content) and the other the necessity (the entrepreneurial form)" [26] [Our translation: p. 126]. It is in this context of a new contemporary hedonism and the constant challenge in the face of uncertainties [24] that we will outline the trajectories of fashion designers, beginning with an exploration of the meaning they themselves give to their activities.

The paradox of the designers as entrepreneurs, due to the fragility of their status and their artistic and cultural legitimacy, in a mass production industry which is changing constantly, invites us to reflect on their peculiar situation. There is an apparent paradox between the status of the artist as opposed to that of the entrepreneur or business person, as we saw in our interviews of designers. For example, some develop new artistic niches, but at the same time try to take the commercial dimension into account and blend the quality and artistic dimension with the business dimension. The eco-design shop "La Gaillarde” (Boutique La Gaillarde) promotes several local designers, especially ethical fashion brands from Quebec: Voyou, Kolchic, Atelier b, OÖM Ethikwear, Jennifer Glasgow, etc., which favor the use of recycled and organic textiles [27]:

"All fabrics are sourced in Montreal and great emphasis is placed on sourcing high quality textiles. All patterns are unique, original designs by Jennifer Glasgow” ([27]: Our translation).

"Proud of the positive and engaged message our clothing conveys, OÖM clothes are made entirely of organic cotton and eco-responsible fabrics like $70 \%$ recycled cotton and recycled polyester. They are manufactured by socially engaged Canadian organisations” ([27]: Our translation).

"To create our collection, what we like is to [push further] for our clients, and then bring back to more simple design [while keeping] a little touch of creativity; this gives something less common, less commercial... We try to buy as many fabrics from Québec, we work only with biological cottons or fibers. We develop our own colors, we print ourselves. We don't look at trend books, we work in a more conceptual way, in our own creative way..." (EDR5, our interview).

The nuances of the business model (creative or commercial, designer versus manufacturing) challenge the relationship to work in opposite ways: work or labor, that is the non-alienated labor characteristic of the artistic profession [24], or otherwise an alienated type of work. Moreover, the appreciation of the practice of the profession can be evaluated by the importance given to the creative or to the entrepreneurial side (opposition between the creator/artisan and the manufacturer). Those who devote most of their activity and time to create are opposed to those who favor the commercial aspect of the activity. One designer, who recognizes herself in the commercial or market model says that what counts for her when she designs clothing is that it is functional and that someone can wear it (DR3, our interview). She refers to the well-known designer, Denis Gagnon, saying he does 
mainly artistic clothes, which could be exhibited: “we could almost make an exhibition” of his clothes (DR3), and indeed the Montreal Museum of Fine Arts did exhibit his designs and clothes a few years ago. However, one respondent warns of the danger of being only an artisan and neglecting the business side (production, distribution) of the profession (DP2, our interview), he adds: "It is a terrible state of fragility" (DP2) because if shops do not follow or do not sell products, people and companies can fail and disappear from the fashion world.

In the present context, innovation is put forward as a possible means of achieving economic recovery and for some authors, this permanent call for innovation is a symptom of capitalism [24]. According to this view, the artist is expected to fulfill a pioneering role ${ }^{7}$ [24] that enables him or her to stand out in a competitive market [24] and to work for his or her recognition. While media networks provide reputation and influence in the world of fashion, or "success in the glamorous" (ED1, our interview), according to some, the commercial or entrepreneurial success which often follows can sometimes be an obstacle to creativity, as some of our interviewees indicate.

Yet, despite political expectations or market requirements, a major conflict weighs on the very identity of artistic professions [28]-[30]. Quite similar to the relationship between the creative dimension and the entrepreneurial aspect, discussed above, this conflict can be described as follows:

There exists an established tension between creative freedom and commercial imperatives, to prevent creativity from being stifled by management. Artistic activities are essentially based on creative processes that cannot be planned, directed or controlled without risk of being exhausted [31]. [Our translation: p. 11]

In fact, for a fashion designer, having talent is not enough and genuine entrepreneurial skills are also essential. Throughout his or her career, the designer will develop strategic relationships with customers, intermediaries (city, governments, sponsors, etc.) and the media. To do this, he or she must have a clear understanding of the different institutional, media, business and social environments.

Throughout the various stages of an artistic career, we can highlight the presence of at least four key dimensions: the building of a reputation, the construction of authenticity, the maintenance of meaningful relationships, and the management of paradoxes [31] [Our translation: p. 8]

It is in the mediation between creativity, innovation and competiveness (distinction, actions, niches, etc.) that career inequalities may appear. A freelance fashion designer is creator and entrepreneur at the same time. Here, the notion of diffuse creativity proves useful. Introduced by Nicolas-Le Strat [26], the term serves as an umbrella term for the entire range of practices starting with the conception of the idea, and thus covers practices that refer more to artisanship and others that are more artistic.

On the one hand the entrepreneurial dimension motivated by career goals of fashion designers can be attributed to, in our opinion, purposeful rational actions. On the other hand, the artistic dimension of the craft, determined by the notion of vocation and conducted as a creative act, is based on an axiological rationality [13]. We consider that these two aspects of the profession use distinct types of action, which invites us to consider how the resources deployed by the actor to pursue professional projects are constructed around a subjective dimension that is unique to the process of creativity and its intended and unintended effects on the development of his or her career. Let us now turn to the case of one designer to better illustrate our point.

\subsection{The Case of Jean-Claude Poitras: A Creative and an Entrepreneur}

The example of the well-known and confirmed designer Jean-Claude Poitras is an excellent one. Having lived through several generations of designers and the history of fashion, his career seems exemplary. Once he had a well-established reputation in the media, the designer wanted to democratize fashion and decided in 1972 to get into the sector of the ready-to-wear, saying: "I'm finally not satisfied to to create collections that interest the people media and the press, and a few upscale shops...” (Jean-Claude Poitras, DP, our interview). Jean-Claude Poitras admits he could never have entered the US market without developing new collaborations. So he joined with a manufacturer and his trademark Bof! finally met a favorable reception from the public, at a time when competition in the apparel industry was not what it is today. However, the designer said he remained true to his artistic approach which was to seek the purity of lines, shapes, beautiful materials, etc. "I started to have a real pretty great commercial success... But people could always recognize my style, I think...” (ibid., our interview).

\footnotetext{
${ }^{7}$ See Schumpeter, innovation as creative destruction.
} 
However, the designer would chose different stores when he was selling high fashion or otherwise of ready-to-wear.

As he mentions: "Holt Renfrew and Ogilvy, they bought my Jean-Claude Poitras collection while in Hudson's Bay stores, they bought Bof! by Jean-Claude Poitras. So it was a bit the idea of high fashion with respect to ready-to-wear kind of... I sold at Bergdoff Goodman in New York...” (Jean-Claude Poitras, our interview).

Poitras thus had access to a double form of success, with the media for the artistic side and with business for the ready-to-wear. In his case, this strengthened his reputation. Overwhelmed by a growing, international demand, he finally gave up the commercial side of the ready-to-wear business, saying:

After a media success, I reached a commercial success, but there was endless criticism from the fashion design sector... You know, I was like lemon that was being pressed, so at some point, I had a period of rebellion, and I told myself: "No, I do not want to stick to these trends at all costs, I know how far to go in the compromise, but I do not want to go too far, I want to stay true to who I am" (Jean-Claude Poitras, our interview).

The designer had already built his reputation, and finally decided to choose very specialized niches (high end uniforms, design, etc.), and to work on specific projects for several companies. He thus has had a career which shows quite some flexibility over his life course and various events had an impact on his career as is expected in the Life Course perspective.

\subsection{Reputation and the Fragility of the Designers' Careers}

Access to reputation and keeping a reputation remain especially fragile career stages, as is the case for novice designers and the newcomers to the industry who are starting to be known. This is why it is necessary to continually focus on one's reputation: "You know, your reputation, it follows you forever... Just do a little something, it's always there, anything can happen, it's very important” (EDC.2, our interview). The development of a reputation requires the constant equilibrium between a commercial success and a media (more artistic) success. The creative dimension and the artistic identity are the source of media success. The uncertain race to establish a reputation highlights the fragility of a system in which those who fall give way to those that are going up the ladder, becoming known, but it seems that the stabilization of the reputation system is never acquired in the fashion business even when the "survival stage" is overcome. There is a huge challenge in regulating success and actions (creative/commercial) and it is extremely difficult to find the right equilibrium to ensure success and make it out of the most precarious situations of the beginning of the career.

The most fragile, emerging designers know that, if they do not consolidate their business model, they will eventually disappear and be replaced by others. The commercial dimension is often absent or neglected with the emerging young designers. Emerging designers are characterized more in terms of movement and number of years "because they can emerge and disappear. It's always a question of how to make things last" (RD.2, our interview). For this group of emerging designers, especially the category which we chose to call the emerging comets, they can be known for their "creative genius" (ISA.2, our interview) and they add to the circle of local fashion as they represent the hope of renewal. Although they have created three to four collections (ISA.2, our interview), many of them do not yet pass the "survival stage" because they are at a delicate stage of their career (ISA.2, our interview). They have a great talent, but can disappear very suddenly (ISA.2, our interview). Therefore, to survive, the designer must engage in competition both in management aspects (production, distribution) as well as in terms of creative individualization, distinguishing himself or herself from the standard garment market.

A beginner designer who suddenly encounters a media success is quickly seen as having possibilities to develop a career. Although the career may be fragile over time, the climb may however be assessed over several seasons or collections. It is only those who present international excellence and are recognized for this that can stabilize their trajectory and become established designers.

In the group of well-established and well-recognized designers, there seems to be a balance between the creative and the commercial dimensions. They are characterized by a commercial dimension, but also by an important rise in singularity, which is achieved through creativity, artistic flair, the contribution of innovation, and in the end, a stabilization of their business model. Yet within this group, the category which we have called the creative elite, is one that has a more or less fragile business model, a model which is not yet consolidated, with some entrepreneurial weaknesses. Some of these designers have local and national distribution, while others 
have their own shop (designer type shop) and can reach a turnover of $\$ 150,000$. They produce locally and do little outsourcing. They produce designer clothing, high-end ready-to-wear, with relatively high prices. They produce customized, limited productions, often unique pieces.

These creative small designers, often self-employed or small businesses, have little means of support and struggle to join the fashion scene and even associations of designers. Moreover, the precarious nature of self-employment makes it "difficult to participate in associations and events" (IIAS.2-2, our interview) because their work is characterized by "many peaks" (IIAS.2-2,) with one-off contracts. It is thus extremely challenging for this group of small designers to make their way into the fashion scene and develop a career. This is a huge challenge in terms of human resources management in the fashion sector.

\section{Conclusions}

We have observed that the reality of the career of the designer has changed dramatically in recent decades, with more precarious conditions for younger designers, but also difficult conditions for more established ones, within the new context of fashion design and other creative industries. Indeed, in light of the changes in the creative industries over the past 20 years, designers have had to adapt to this context, moving from the image of designing custom-fitted clothing to that of the artist/entrepreneur, and to a context of less stable, often precarious "boundaryless" careers [8]. Today, the development of a sustainable business model seems to be a major concern for designers who see their life course perspectives become somewhat more uncertain in the "boundaryless" context.

In the 1950s, the concept of the "business model" was introduced and pertained to management and economics. The business model can be defined as the structuring of an organization to ensure its viability and revolves around the production value of the company, the internal and external organization and the resources and skills held by the company. The transformation of the business model in the fashion industry in Montreal presents a panorama of diverse models. While the dominant haute couture model of the 50s was not totally secure, it was more so than the present type of careers; indeed, we see the emergence of a typology of "uncertain", precarious careers in which a hybrid category of fashion designers position themselves in various places along a continuum of two poles: on the one hand those who work for a manufacturing company and on the other hand those who work directly in the creative industry, who start their own business or who work for another designer. The latter group has a more precarious situation than the first, and it illustrates how the business model of the creative economy has evolved. Personified by the fashion designer/entrepreneur, this model incorporates not only the creative talent of this professional but also his or her reputation, network and entrepreneurial skills. However, a reputation and a network are not so easy to build, so many young designers have difficulty establishing themselves and making a living out of their art.

Over the years, the image of fashion designer has changed, as we have seen, approximating more and more that of the entrepreneur and challenging traditional human resources and business models. We moved from the image of couturier to that of fashion designer/entrepreneur. The fashion designer/entrepreneur is in fact an independent contractor with his or her own studio and boutiques, either with or without other distribution networks. Some big names fall into this category in the case of Montreal, for example Marie Saint-Pierre or Mariouche by Harricana, who in fact hire other designers to work on their brand. In these cases, the designer works as artistic director. Here, the final product is a reflection of the universe of the fashion creator. And in that case, the designers must meet the challenge of being an independent entrepreneur in addition to sustaining their creativity. In this situation, creativity is the key to the success of their business model; but, as in all creative careers, it is not enough. Entrepreneurship and creativity are thus becoming more and more closely aligned.

Boltanski \& Chiapello [32] observe that the post-industrial society favors a city organized by projects in reference to the flexible world constituted by individuals working in projects [32], and with multiple collaborations. These professional trajectories, characteristic of artistic professions, are structured around a "system organized around projects" [24] and they require a lot of flexibility in work. We can thus put forward the idea that the creative, artistic model of career, which requires much flexibility [24] and constant adaptation may be paving the way for more global transformations of professional spaces and human resources in other sectors.

\section{References}

[1] Becker, H.S. (1988) Les mondes de l'art [The Worlds of Art]. Flammarion, Paris. 
[2] Lowe, G. and Schellenberg, G. (2000) What's a Good Job? The Importance of Employment Relationships. CPRN Research Report No. 8. Canadian Policy Research Network, Ottawa.

[3] Tremblay, D.-G. (2004) Économie du travail [Labour Economics]. Descarries/St-Martin Editor, Montréal.

[4] Tremblay, D.-G. and Huesca Dehesa, A.D. (2016) Montréal, Creative City and Immigrant Creatives: Can the Art World and Entrepreneurship Be Brought Together? Journal of Human Resources and Social Sustainability, 4, 55-67. http://dx.doi.org/10.4236/jhrss.2016.42007

[5] Menger, P.-M. (2006) Artistic Labor Markets: Contingent Work, Excess Supply and Occupational Risk Management. In: Ginsburgh, V. and Throsby, D., Eds., Handbook of the Economics of Art and Culture, Vol. 1, Amsterdam, Elsevier, Chapter 22, 765-811. http://dx.doi.org/10.1016/S1574-0676(06)01022-2

[6] Menger, P.-M. (2009) Le travail créateur [Creative Work]. Gallimard, Paris.

[7] Herzenberg, S.A., Alic, J.A. and Wial, H. (1998) New Rules for a New Economy. Employment and Opportunity in Postindustrial America. Cornell University Press, Ithaca.

[8] Arthur, M., Claman, J. and DeFillippi, R. (1995) Intelligent Enterprise, Intelligent Careers. Academy of Management Executive, 9, 7-20. http://dx.doi.org/10.5465/ame.1995.9512032185

[9] Tremblay, D.-G. and Huesca Dehesa, A.D. (2016) Being a Creative and an Immigrant: What Support for the Development of a Creative Career? Journal of Workplace Rights. https://uk.sagepub.com/en-gb/eur/journal-of-workplace-rights/journal202427

[10] Tremblay, D.-G. and Yagoubi, A. (2014) Knowledge Sharing and Development of Creative Fashion Designers’ Careers: The Role of Intermediary Organisations. International Journal of Knowledge-Based Development, 5, 191-208. http://dx.doi.org/10.1504/IJKBD.2014.063991

[11] Anxo, D. and Boulin, J.Y. (2006) The Organisation of Time over the Life Course. European Studies, 8.

[12] Bernard, P. (2007) The Life Course Perspective. Conference Presentation at the HRSDC PRI Workshop, Ottawa, 13-14 December 2007.

[13] Yagoubi, A. (2015) De la singularisation des trajectoires à la coopération des mondes de la mode à Montréal: Le designer en régime de reputation. Ph.D. Thesis, Université du Québec à Montréal, Montréal.

[14] Paillé, P. and Mucchielli, A. (2008) L’analyse qualitative en sciences humaines et sociales. Armand Colin, Paris.

[15] Royer, M. (2007) Étude de triangulation du discours public [A Study of Triangulatio of Public Discourse]. In: de Chartier, L. and Lafrance, d'A.-A., Eds., Laboratoire d'analyse de presse, Chaire en relations publiques de l'UQAM, Montréal.

[16] Gérald, B. (2004) Dicomode. Dictionnaire de la mode au Québec de 1900 à nos jours [Dictionary of Fashion in Québec, from 1900 till Today]. Fides, Montreal.

[17] Choco, M.H., Bourassa, P. and Baril. G. (2003) Le design au Québec. Industriel, graphique, de mode [Design in Québec: Industrial, Graphic, and Fashion]. Les Éditions de l’Homme.

[18] Apparel Human Resources Council (2011) Pressing Ahead: Canada’s Transforming Apparel Industry 2011 Labour Market Information Study. Milstein \& Co. Consulting, 1-50. WWW.Apparelconnexion.CA

[19] UK Trade \& Investment (2009) Creative Industries UK. 90 p.

[20] Throsby, D. (2001) Economics and Culture. Cambridge University Press, Cambridge.

[21] UNESCO (1996) Notre diversité créatrice [Our Creative Diversity]. UNESCO, Paris.

[22] Florida, R. (2002) The Rise of the Creative Class: And How It's Transforming Work, Leisure, Community and Everyday Life. Basic Books, New York.

[23] Stolarick, K., Florida, R. and Louis, M. (2005) Montréal, ville de convergences créatives: Perspectives et possibilités [Montreal, a City of Convergent Creativity]. Catalytix, Montréal.

[24] Menger, P.-M. (2002) Portrait de l'artiste en travailleur. Métamorphoses du capitalisme [A Portrait of the Artist as a Worker-Metamorphosis of Capitalism]. Éditions du Seuil, Paris.

[25] Bell, D. (1979) Les contradictions culturelles du capitalisme [Cultural Contradictions of Capitalism]. PUF, Paris.

[26] Nicolas-Le Strat, P. (1998) Une sociologie du travail artistique [A Sociology of Artistic Work]. L’Harmattan, Paris.

[27] Couzinou, V. (No Date) À la découverte des designers du Québec, Elle Québec. http://www.ellequebec.com/mode/tendances/a-la-decouverte-des-designers-du-quebec/a/25544/3

[28] Heinich, N. (1991) Peut-on parler de carrières artistiques? [Can We Talk about Artistic Careers?] Cahiers de Recherche Sociologique, 43-54. http://dx.doi.org/10.7202/1002127ar

[29] Heinich, N. (1995) Façons d’être écrivain. L’identité professionnelle en régime de singularité [Ways of Being a Writer. Professional Identity in a Regime of Singularity]. Revue Française de Sociologie, 36, 499-524. 
http://dx.doi.org/10.2307/3322166

[30] Heinich, N. (2005) L’élite artiste. Excellence et singularité en régime démocratique [The Artistic Elite. Excellence and Singularity in a Democratic Regime]. Gallimard, Paris.

[31] Davel, E., Lefèvre, F. and Tremblay, D.-G. (2007) Carrière artistique et entrepreneuriat: La créativité comme voie de recherche [Artistic Careers and Entrepreneurship: Creativity as an Avenue for Research]. The 5th International Congress of the Entrepreneurship Academia (Académie de l'Entrepreneuriat), Sherbrooke, 4-5 October 2007.

[32] Boltanski, L. and Chiapello, E. (2011) Le Nouvel Esprit du capitalism [The New Spirit of Capitalism]. Gallimard, Paris.

\section{Websites}

UNESCO

http://portal.unesco.org/culture/fr/ev.php-URL_ID=26390\&URL_DO=DO_TOPIC\&URL_SECTION=201.html, consulted 28 avril 2010.

FASHION CITIES

http://www.arts.ac.uk/fashioncities.htm, consulted 12 Mai 2010. Conférence du Vendredi 29 avril et Samedi 30, 2005.

Fashion Montréal

www.montrealcartedemode.com

\section{Interview Codes}

Micro

ED: Emerging designer

PD: Pioneer Designer

RD: Renowned designer

Méso

IISA: Intermediate Intersectorial Actors

ISA: Intermediate Sectorial Actors

IP: Political Intermediates

IPI: Intermediate Promoting Industry Association

\section{Submit or recommend next manuscript to SCIRP and we will provide best service for you:}

Accepting pre-submission inquiries through Email, Facebook, LinkedIn, Twitter, etc.

A wide selection of journals (inclusive of 9 subjects, more than 200 journals)

Providing 24-hour high-quality service

User-friendly online submission system

Fair and swift peer-review system

Efficient typesetting and proofreading procedure

Display of the result of downloads and visits, as well as the number of cited articles

Maximum dissemination of your research work

Submit your manuscript at: http://papersubmission.scirp.org/ 